\title{
Influence of Row Spacing and Nitrogen Levels on Growth Rate and Nitrogen Uptake in Japanese Mint (Mentha arvensis L.)
}

\author{
P. S. Mahantesh ${ }^{1 *}$, P. M. Gangadharappa ${ }^{2}$, J. S. Hiremath ${ }^{3}$, \\ K. M. Shivakumar ${ }^{4}$, Y. Ravi $^{5}$ and D. S. Bhat ${ }^{1}$ \\ ${ }^{1}$ Department of Plantation, Spices, Medicinal and Aromatic Crops, UHS, Bagalkot, \\ Karnataka-587104. India \\ ${ }^{2} \mathrm{COH}$, Munirabad, UHS, Bagalkot, Karnataka -587104. India \\ ${ }^{3}$ Plantation, Spices, Medicinal and Aromatic Crops, UHS, Bagalkot, Karnataka-587104. India \\ ${ }^{4}$ Department Soil Science and Agricultural Chemistry, UHS, Bagalkot, \\ Karnataka-587104. India \\ ${ }^{5}$ Spices, Plantation \&Medicinal and Aromatic Plants, ICAR-NRCSS, Ajmeer, \\ Rajasthan-305206. India \\ *Corresponding author
}

A B S T R A C T

\begin{tabular}{|l|}
\hline K e y w o r d s \\
$\begin{array}{l}\text { Growth, Yield, Nitrogen } \\
\text { levels, Spacing, Days } \\
\text { after planting. Nitrogen } \\
\text { uptake }\end{array}$ \\
\hline Article Info \\
\hline $\begin{array}{l}\text { Accepted: } \\
\text { 15 May } 2018 \\
\text { Available Online: } \\
\text { 10 June } 2018\end{array}$ \\
\hline
\end{tabular}

\section{Introduction}

Japanese mint is a perennial herb growing about $60-80 \mathrm{~cm}$ in height and under favourable conditions may attain a height upto $100 \mathrm{~cm}$. Leaves are $2.5-5 \mathrm{~cm}$ long, oblongovate. Flowers are in auxiliary whorls. Flowers appearing in May-June and again in September-November under cultivation. The cultivation of Japanese or corn mint originated
A field study was conducted during 2015-16 to investigate the effect of row spacing (30 $\mathrm{cm}, 45 \mathrm{~cm}$ and $60 \mathrm{~cm})$ and nitrogen levels $(50,100,150$ and $200 \mathrm{~kg} / \mathrm{ha})$ on growth of Japanese mint (Mentha arvensis L.). The result revealed that between 45- 90 days after planting, the highest absolute growth rate $(1.13 \mathrm{~g} / \mathrm{plant} /$ day $)$ was recorded at $60 \mathrm{~cm}$ row spacing. While, the crop growth rate $\left(6.87 \mathrm{~g} / \mathrm{m}^{2} /\right.$ day $)$ was highest at $30 \mathrm{~cm}$ row spacing. Highest nitrogen content in plant $(2.05 \%)$ was recorded at wider row spacing of $60 \mathrm{~cm}$. While, the nitrogen uptake was highest $(90.51 \mathrm{~kg} / \mathrm{ha})$ at closer row spacing of $30 \mathrm{~cm}$. Between 45- 90 after planting, the highest absolute growth rate $(1.14 \mathrm{~g} / \mathrm{plant} /$ day $)$, crop growth rate $\left(6.04 \mathrm{~g} / \mathrm{m}^{2} /\right.$ day), nitrogen content in plant $(2.40 \%)$ and nitrogen uptake $(115.16 \mathrm{~kg} / \mathrm{ha})$ were maximum with the application of $150 \mathrm{~kg} \mathrm{~N}$ per ha.

from Brazil and China. Subsequently, China and India overtook Brazil and more recently India has taken the leading position in cultivation of this essential oil yielding plant.

The recovery of oil from the herb is $0.5-0.8$ per cent. Oil is obtained through steam distillation. The oil is of golden yellow colour, containing not less than 75 percent menthol. Japanese Mint has a history of traditional and 
herbal medicine use, similar to most other mints. It is antiseptic, used as a digestive aid, for treating fevers, headaches and minor ailments. The mint oil is used for the production of natural menthol, dementhalised oil is for flavouring mouth washes, tooth paste and pharmaceutical preparations. In medicine, it is used against stomach disorders, rheumatism, in ointments for headaches, in cough drops, inhalations etc. The oil has a bitter cooling taste, harsh odour and is the principal source of menthol. It is used in combating cold, used as an ingredient in cough drops and related pharmaceuticals, dentifrices, cosmetics, mouth washes, scenting of tobacco products. The essential oil in Mentha arvensis is said to be approximately the equivalent of that produced from Peppermint. The essential oil is produced commercially and sometimes substituted for the more expensive peppermint oil. The resulting oil is often called 'Japanese Herbal Oil'.

\section{Materials and Methods}

A field experiment was conducted to study the effect of row spacing and nitrogen levels on growth of Japanese mint (Mentha arvensis L.) at the Department of Plantation, Spices, Medicinal and Aromatic Crops, Kittur Rani Channamma College of Horticulture, Arabhavi, University of Horticultural Sciences, Bagalkot during 2015-16. The experiment was laid out in split plot design with twelve treatments and three replications, considering spacing as main plot and nitrogen levels as sub plot. The experimental site was having sandy clay loam (vertisols) soil with neutral $\mathrm{pH}$. Soil samples were collected from a depth of $0-15 \mathrm{~cm}$ from the experimental site adopting the standard procedure and the composite samples were used for analysis of physico-chemical properties. Stolons were planted horizontally in furrows about 2.5- 4.0 $\mathrm{cm}$ deep according to spacing treatments. The crop was harvested 100 days after planting. Harvesting was done with sharp sickles.

Phosphorous and potassium fertilizers at the rate of 50 and $40 \mathrm{~kg}$ per ha in the form of single super phosphate and muriate of potash respectively were uniformly applied to all the plots as basal dose. The fertilizer mixture was applied by broadcasting uniformly in rows to individual plots and mixed thoroughly in to the soil.

The experimental plots were provided with the calculated quantity of fertilizers as per the treatments. Out of total quantity, half dose of nitrogen and full dose of phosphorous and potash were supplied as basal dose at the time of planting. The remaining half quantity of nitrogen was given as top dressing at 30 days after planting.

\section{Absolute growth rate (AGR) (g/plant/day)}

It expresses the increasing dry weight per plant in unit time and was calculated by using the following formula (Radford, 1967) and expressed as g/plant/day.

$\mathrm{AGR}=\frac{\left(\mathrm{W}_{2}-\mathrm{W}_{1}\right)}{\left(\mathrm{t}_{2}-\mathrm{t}_{1}\right)}$

Where,

$\mathrm{W}_{1}=$ Total dry weight of the plant $(\mathrm{g})$ at time $\mathrm{t}_{1}$

$\mathrm{W}_{2}=$ Total dry weight of the plant $(\mathrm{g})$ at time $\mathrm{t}_{2}$

$\mathrm{t}_{2}-\mathrm{t}_{1}=$ Time interval in days.

Crop growth rate (CGR) $\left(\mathrm{g} / \mathrm{m}^{2} / \mathrm{day}\right)$

It is the rate of dry matter production per unit ground area per unit time. It was calculated by 
using the formula given by Watson (1952) and expressed as (g/m $/ \mathrm{m}^{2} /$ day $)$.

$\mathrm{CGR}=\frac{\left(\mathrm{W}_{2}-\mathrm{W}_{1}\right)}{\left(\mathrm{t}_{2}-\mathrm{t}_{1}\right)} \times \frac{1}{\mathrm{~A}}$

$\mathrm{W}_{1}=$ Dry weight of the plant at time $\mathrm{t}_{1}$

$\mathrm{W}_{2}=$ Dry weight of the plant at time $\mathrm{t}_{2}$

$\mathrm{A}=$ Land area

\section{Plant analysis}

Dried whole plant samples of leaves, stem and roots were ground to a fine powder separately and the content of nitrogen in the plant tissue was analyzed by using suitable methods of analysis.

The total nitrogen (\%) was determined by Kjeldhal method as outlined by Piper (1966). Plant sample of $1 \mathrm{~g}$ each was digested with digestion mixture $\left(\mathrm{CuSO}_{4}, \mathrm{~K}_{2} \mathrm{SO}_{4}\right.$ and $\mathrm{Se}$ in 10:4:1 ratio) in a digestion chamber along with $25 \mathrm{ml}$ of concentrated sulphuric acid. The digested mixture was then distilled and the ammonia released was trapped in four per cent boric acid with mixed indicator. This was titrated against standard sulphuric acid.

\section{Soil analysis}

The nitrogen uptake was determined by using Micro - Kjeldhal digestion and distillation as outlined by Piper (1966) and expressed in $\mathrm{Kg}$ per hectare.

\section{Results and Discussion}

The row spacing levels had significant effect on absolute growth rate. Between 45 - 90 DAP, the maximum (1.13 g/plant/day) AGR was observed in row spacing of $60 \mathrm{~cm}\left(\mathrm{~S}_{3}\right)$. While the minimum (0.93 g/plant/day) AGR was noticed at $30 \mathrm{~cm}$ row spacing $\left(\mathrm{S}_{1}\right)$. This might be due to higher dry matter accumulation per unit area. Closer row spacing of $30 \mathrm{~cm}\left(\mathrm{~S}_{1}\right)$ had significant effect on CGR and recorded more $\left(6.87 \mathrm{~g} / \mathrm{m}^{2} /\right.$ day $)$ CGR between 45 - 90 DAP. Increased CGR at closer row spacing might be due to increase in plant population per unit area which led to higher dry matter accumulation. Similar findings were also obtained by Chinnabbai (1991) in Mentha viridis.

Between 45 - 90 DAP, the highest (1.14 g/plant/Day) AGR was recorded at nitrogen level of $\mathrm{N}_{3}(150 \mathrm{~kg} / \mathrm{ha})$, While the minimum (0.88 g/ plant/Day) AGR was observed in $\mathrm{N}_{1}$ (50 kg/ha). This might be due to better vegetative growth in terms of highest plant height, number of leaves, branches and total dry matter accumulation in the plants supplied with higher levels of nitrogen. The maximum $\left(6.04 \mathrm{~g} / \mathrm{m}^{2} /\right.$ day) CGR was recorded with the application of $\mathrm{N}_{3}(150 \mathrm{Kg} / \mathrm{ha})$. This might be due to reduced plant height, fewer number of branches and leaves, smaller leaf area at lower dose of nitrogen. Higher dose of nitrogen helps in dry matter accumulation in plants. Similar trend was observed by Rai et al., (1977) in Japanese mint and Santhosh et al., (2010) in garden cress.

Significant difference was observed for nitrogen content in plants due to row spacing. Nitrogen content was highest $(2.05 \%)$ in wider row spacing of $60 \mathrm{~cm}\left(\mathrm{~S}_{3}\right)$. This might be due to the fact that in wider spacing there was possibility for the better shoot growth due to light penetration which in turn increases root growth and helps in better uptake of nitrogen from the soil. Plants grown at $30 \mathrm{~cm}$ row spacing recorded maximum nitrogen uptake $(90.51 \mathrm{~kg} / \mathrm{ha})$ and minimum $(76.08$ $\mathrm{kg} / \mathrm{ha})$ was noticed at $60 \mathrm{~cm}\left(\mathrm{~S}_{3}\right)$. This supports the fact that more the plant population more will be the nitrogen uptake per unit area. Similar results were reported by, Rao et al., (1990) in palmrosa and Bali et al., (1992) in dill. 
Table.1 Effect of row spacing and nitrogen levels on Absolute growth rate and crop growth rate in Japanese mint (Mentha arvensis L.)

\begin{tabular}{|c|c|c|c|c|c|c|c|c|c|c|}
\hline \multirow[t]{3}{*}{ Treatments } & \multicolumn{5}{|c|}{ AGR (g/ plant/Day) } & \multicolumn{5}{|c|}{ CGR $\left(\mathrm{g} / \mathrm{m}^{2} / \mathrm{day}\right) * 10^{2}$} \\
\hline & \multicolumn{5}{|c|}{45 - 90 DAP } & \multicolumn{5}{|c|}{45 - 90 DAP } \\
\hline & $\mathbf{N}_{1}$ & $\mathbf{N}_{2}$ & $\mathbf{N}_{3}$ & $\mathbf{N}_{4}$ & Mean & $\mathbf{N}_{1}$ & $\mathbf{N}_{2}$ & $\mathbf{N}_{3}$ & $\mathbf{N}_{4}$ & Mean \\
\hline $\mathbf{S}_{1}$ & 0.76 & 0.89 & 1.09 & 0.98 & 0.93 & 5.60 & 6.58 & 8.07 & 7.24 & 6.87 \\
\hline $\mathbf{S}_{2}$ & 0.89 & 1.04 & 1.13 & 1.07 & 1.03 & 4.39 & 5.12 & 5.56 & 5.27 & 5.08 \\
\hline $\mathbf{S}_{3}$ & 1.01 & 1.15 & 1.21 & 1.17 & 1.13 & 3.76 & 4.25 & 4.50 & 4.33 & 4.21 \\
\hline Mean & 0.88 & 1.02 & 1.14 & 1.07 & & 4.58 & 5.31 & 6.04 & 5.61 & \\
\hline \multicolumn{11}{|c|}{ For comparison of mean } \\
\hline & & \multicolumn{2}{|c|}{ S.Em \pm} & \multicolumn{2}{|c|}{ CD@5\% } & \multicolumn{2}{|c|}{ S.Em \pm} & & \multicolumn{2}{|c|}{ CD@5\% } \\
\hline \multicolumn{2}{|c|}{ Row spacing(S) } & \multicolumn{2}{|c|}{0.031} & \multicolumn{2}{|c|}{0.121} & \multicolumn{2}{|c|}{0.146} & & \multicolumn{2}{|c|}{0.575} \\
\hline \multicolumn{2}{|l|}{ Nitrogen (N) } & \multicolumn{2}{|c|}{0.029} & \multicolumn{2}{|c|}{0.086} & \multicolumn{2}{|c|}{0.150} & & \multicolumn{2}{|c|}{0.447} \\
\hline \multicolumn{2}{|c|}{$\mathrm{S}$ at same level of $\mathbf{N}$} & \multicolumn{2}{|c|}{0.053} & \multicolumn{2}{|c|}{ NS } & \multicolumn{2}{|c|}{0.268} & & \multicolumn{2}{|c|}{ NS } \\
\hline \multicolumn{2}{|c|}{$\begin{array}{l}\mathrm{N} \text { at same or different } \\
\text { level of } \mathrm{S}\end{array}$} & \multicolumn{2}{|c|}{0.050} & \multicolumn{2}{|c|}{ NS } & \multicolumn{2}{|c|}{0.260} & & \multicolumn{2}{|c|}{ NS } \\
\hline \multicolumn{2}{|c|}{ AGR: Absolute growth rate } & \multicolumn{4}{|c|}{ CGR: Crop growth rate } & after pl & & & & \\
\hline \multicolumn{2}{|c|}{ Main plot treatments $(S)$} & \multicolumn{4}{|c|}{ Sub plot treatments $(\mathbf{N})$} & & & & & \\
\hline $\begin{array}{l}\mathrm{S}_{1}: 30 \mathrm{~cm} \\
\mathrm{~S}_{2}: 45 \mathrm{~cm} \\
\mathrm{~S}_{3}: 60 \mathrm{~cm}\end{array}$ & & \multicolumn{4}{|c|}{$\begin{array}{l}\mathrm{N}_{1}: 50 \mathrm{~kg} / \mathrm{ha} \\
\mathrm{N}_{2}: 100 \mathrm{~kg} / \mathrm{ha} \\
\mathrm{N}_{3}: 150 \mathrm{~kg} / \mathrm{ha} \\
\mathrm{N}_{4}: 200 \mathrm{~kg} / \mathrm{ha}\end{array}$} & & & & & \\
\hline
\end{tabular}


Table.2 Effect of row spacing and nitrogen levels on nitrogen content in plant and nitrogen uptake in Japanese mint (Mentha arvensis L.)

\begin{tabular}{|c|c|c|c|c|c|c|c|c|c|c|}
\hline \multirow[t]{2}{*}{ Treatments } & \multicolumn{5}{|c|}{ Nitrogen content (\%) } & \multicolumn{5}{|c|}{ Nitrogen uptake (Kg/ha) } \\
\hline & $\mathbf{N}_{1}$ & $\mathbf{N}_{2}$ & $\mathbf{N}_{3}$ & $\mathbf{N}_{4}$ & Mean & $\mathbf{N}_{1}$ & $\mathbf{N}_{2}$ & $\mathbf{N}_{3}$ & $\mathbf{N}_{4}$ & Mean \\
\hline$\overline{S_{1}}$ & 1.15 & 1.54 & 2.15 & 2.03 & 1.71 & 47.85 & 76.21 & 127.41 & 110.59 & 90.51 \\
\hline $\mathbf{S}_{\mathbf{2}}$ & 1.38 & 1.72 & 2.45 & 2.12 & 1.91 & 47.14 & 70.01 & 112.77 & 91.92 & 80.46 \\
\hline $\mathbf{S}_{\mathbf{3}}$ & 1.50 & 1.83 & 2.62 & 2.26 & 2.05 & 47.70 & 66.08 & 105.31 & 85.25 & 76.08 \\
\hline Mean & 1.34 & 1.69 & 2.40 & 2.13 & & 47.56 & 70.76 & 115.16 & 95.92 & \\
\hline \multicolumn{11}{|c|}{ For comparison of mean } \\
\hline & & \multicolumn{2}{|c|}{ S.Em \pm} & \multicolumn{2}{|c|}{ CD@ $5 \%$} & \multicolumn{3}{|c|}{ S.Em \pm} & \multicolumn{2}{|c|}{ CD@5\% } \\
\hline Row spacing(S) & & \multicolumn{2}{|c|}{0.057} & \multicolumn{2}{|r|}{0.225} & \multicolumn{3}{|c|}{2.253} & \multicolumn{2}{|c|}{8.848} \\
\hline \multicolumn{2}{|l|}{ Nitrogen $(\mathbf{N})$} & & 0.072 & & 0.213 & \multicolumn{3}{|c|}{2.933} & \multicolumn{2}{|c|}{8.714} \\
\hline \multicolumn{2}{|c|}{ S at same level of $\mathbf{N}$} & & 0.122 & & NS & \multicolumn{3}{|c|}{4.942} & \multicolumn{2}{|c|}{ NS } \\
\hline \multicolumn{2}{|c|}{$\mathbf{N}$ at same or different level of $\mathbf{S}$} & & 0.124 & & NS & \multicolumn{3}{|c|}{5.079} & \multicolumn{2}{|c|}{ NS } \\
\hline \multicolumn{6}{|l|}{ Main plot treatments $(\mathbf{S})$} & & & & & \\
\hline $\begin{array}{l}\mathrm{S}_{1}: 30 \mathrm{~cm} \\
\mathrm{~S}_{2}: 45 \mathrm{~cm} \\
\mathrm{~S}_{3}: 60 \mathrm{~cm}\end{array}$ & \multicolumn{3}{|c|}{$\begin{array}{l}\mathrm{N}_{1}: 50 \mathrm{~kg} / \mathrm{ha} \\
\mathrm{N}_{2}: 100 \mathrm{~kg} / \mathrm{ha} \\
\mathrm{N}_{3}: 150 \mathrm{~kg} / \mathrm{ha} \\
\mathrm{N}_{4}: 200 \mathrm{~kg} / \mathrm{ha}\end{array}$} & & & & & & & \\
\hline
\end{tabular}


Significant difference in nitrogen content in plants was due to the nitrogen. Application of $150 \mathrm{~kg}$ NPK per ha $\left(\mathrm{N}_{3}\right)$ recorded highest nitrogen content $(2.40 \%)$ in plant and the lowest nitrogen content of 1.34 per cent was observed in $\mathrm{N}_{1}(50 \mathrm{~kg} \mathrm{NPK} / \mathrm{ha})$. This might be due to the higher available nitrogen in the soil due to application of nitrogenous fertilizers to the soil and their preferential absorption. Similar results were noticed by, Saxena and Singh (1996) in Japanese mint. The highest nitrogen uptake to the tune of $115.16 \mathrm{~kg}$ per ha was recorded due to application of $150 \mathrm{~kg} \mathrm{~N}$ per ha $\left(\mathrm{N}_{3}\right)$ and the lowest nitrogen uptake (47.56 $\mathrm{kg} / \mathrm{ha})$ was observed in plants supplied with $50 \mathrm{~kg} \mathrm{~N}$ per ha $\left(\mathrm{N}_{1}\right)$. The availability of increased level of nitrogen in the soil increased the uptake of nitrogen through the increased growth and dry matter production by the crop. Similar kind of results was recorded earlier by Balyan and Sobti (1990) in Ocimum gratissium and Prakasa rao et al., (2007) in French basil.

\section{References}

Bali, A. S., Sidhu, B. S. and Randhawa, G. S. 1992. Efeect of row spacing and nitrogen uptake, content and quality of dill oil. Ind. J. Agron., 37(3): 633-634.

Balyan, S. S. and Sobti, S. N. 1990. Effect of inter and intra row spacing on growth, yield and eugenol content in Ocimum gratissimum L. (Clocimum). Indian Perfumer, 34: 217-224.

Chinnaibbai, J. 1991. Effect of row spacing and nitrogen level on growth and herbage yield of mint (Mentha viridis L.). M.Sc Thesis, Univ. Agri. Sci. Hyderabad.

Piper, C. S. 1966. Soil and Plant Analysis: Inter-Sciences Publications, Inc., New York.

Prakasa rao, E. V. S., Puttanna, K., Ganesha rao, R. S. and Ramesh, S. 2007. Nitrogen and potassium nutrition of french basil (Ocimum basilicum L.). J. Spices Arom. Crops, 16(2): 99-105.

Radford, P. J. 1967. Growth analysis formulae, their use and abuse. Crop Science, 7:171-178.

Rai, T. B., Singh, J. N. and Singh D. B. 1977. Growth, essential oil and composition of Japanese mint (Mentha arvensis L.). Indian perfumer, 21:59-64.

Rao, B. R., Kailash, S. and Kaul, P. N. 1990. Response of palmrosa (Cymbopogon martini) to plant spacing and nitrogen fertilizer application. Int. J. Trop. Agri., 8(3): 177-183.

Santosh, C., Keshawa, G. L. and Yadav, L. R. 2010. Effect of row spacings and nitrogen levels on productivity of garden cress (Lepidium sativum). Ind. J. Agric. Sci., 80(8): 752-754.

Saxsena, A. and Singh, J. N. 1996. Yield and nitrogen uptake of Japanese mint (Mentha arvensis) under various moisture regimes, mulch application and nitrogen fertilization. J. Med. Arom. Plant Sci., 18: 477-480.

Watson, D. J., 1952, The physiological basis of variation in yield. Advances in Agronomy, 4: 101-145.

\section{How to cite this article:}

Mahantesh P. S., P. M. Gangadharappa, J. S. Hiremath, K. M. Shivakumar, Y. Ravi and Bhat D. S. 2018. Influence of Row Spacing and Nitrogen Levels on Growth Rate and Nitrogen Uptake in Japanese Mint (Mentha arvensis L.). Int.J.Curr.Microbiol.App.Sci. 7(06): 12971302. doi: https://doi.org/10.20546/ijcmas.2018.706.152 